\title{
Alternative Learning and Research Leading to Development
}

\author{
By Jaime Jiménez* \\ Mónica N. Velasco E..$^{\dagger}$
}

The objective of this work is to report an experience of learning and research not following the traditional track, which is successful in preparing individuals to get a doctoral degree and, while getting the credentials, engage in research related to the needs and desires of the regions where they live. The Centre for Innovation and Educational Development (CIDE) is a Mexican private organization created by academics working in public universities, in an effort to contribute to the application of science to solve local/regional problems. The model combines: Problem-based Learning (PBL), self-study as well as group-study, flexible curriculum, intensive use of ICT's, and the acquisition of generic competencies for research. The focus is on learning rather than teaching based on personal and group study carried out by the students concentrating on specific topics of research. CIDE has proved that the preparation of highly qualified, motivated scientists could be done with very limited resources.

Keywords: Alternative learning and research, Community development, Science for development.

\section{Introduction}

The Centre for Innovation and Educational Development (Centro de Innovación y Desarrollo Educativo, CIDE) is an exceptional institution in terms of its generous offering of higher education leading to research at practically no cost. The question raised by its founders is the same as we set up as our research question: how to increase the number of scientists dedicated to local/regional development in Mexico? The answer is given by a set of scholars, not necessarily belonging to mainstream science, who make intensive use of modern information and communication technologies (ICTs) to encourage students to engage in a $\mathrm{PhD}$ program in sciences, via an alternative track that concurrently combines specific learnings with the acquisition of the abilities to carry out independent research. The research topics are usually provided by the own students derived from the needs observed in their own place where they live. In the decade of the 80's, Dr. Miguel Arenas, a scholar from the public educational system, proposed to his colleagues to experiment with a new learning-research paradigm in public institutions located away from the main urban settlements. Both he and his fellow mates argued that:

\footnotetext{
* Scientist, National Autonomous University of Mexico, Mexico.

† Investigadora Cátedras CONACYT, México.
} 
"The education imparted in universities was not appropriate for the learning of students. Mexico needed to produce more scientists to cover national needs and the official system was unable to carry out that work by itself" (CIDE, 2003).

Dr. Arenas and associates gradually developed a learning method that is a combination of Problem-based Learning (PBL), self-study as well as groupstudy, flexible curriculum, intensive use of ICT's, and the acquisition of generic competencies for research. The emphasis in education is changed from teaching to learning. Indeed, these scholars realized that: The objective of education is learning, not teaching (Ackoff and Greenberg 2008: 5) and motivated students and adults learn without being thought; they do so by means they select (ibid: 10). CIDE starts from a didactics addressed to the adult population (andragogy), inter-disciplinary, multi-age and multi-level where students with both different interests and motivations concur to learn how to proceed as a scientist in formation, that is, individuals meet in the same space sharing the knowledge each has and learning from each other (CIDE-CEJUS 2015). One of the most active members of CIDE, Joel López-Pérez along with Susana Juárez-López, put together the principles of the method and baptized it as Método Arenas (Arenas Method) in honor of the academic who initiated this effort (López-Pérez and Juárez-López 2012).

In terms of infrastructure, CIDE lacks any physical installations or laboratories. They meet in edifices belonging to other organizations. The student, whose project requires the use of a laboratory, is recommended by the members of the CIDE network with a scholar who has access to one. Doctoral advisors are not remunerated; they only receive the cost of transportation to the meeting place. The socialization of knowledge, fundamental in the learning process, takes place once per month on weekends in two full intensive workdays. Students and advisors meet to report the students' progress in their personal academic programs. Since these meetings are multi-level, and multithematic, they represent a unique opportunity to learn even outside the particular topic of their research.

Our methodological approach in this research is case-study, stressing participant observation, documental analysis and in-depth interviewing.

\section{Relevant Literature}

\section{Training Scientists to Attend Regional Problems}

Keane and Allison (1999) assert that knowledge and learning represent two necessary elements for the achievement of economic development; therefore training scientists for addressing problems, not necessarily in good currency, is an important issue for the economic South. In fact, as Wu et al. (2008) show, there is a positive correlation between income distribution and level of education per capita. For that reason, all efforts to improve the level of education in a country, as CIDE does, should be most welcome. The above 
leads to understand the need to prepare a larger number of professionals, scientists and technologists that will generate innovations, not only within the overall framework, but also within specific contexts. Sun (2015) emphasizes the need to produce consensus among society to help migrate toward a greater local knowledge generation, which finally will help to provide more ad hoc solutions to specific problems, and may have a favorable effect on the development of regions, not only from an economic point of view but also socially. Caroline Wagner asserts that "The new social structure of science poses significant, although divergent, challenges for both advanced and developing countries" (Wagner 2008: 11). She realizes that "Developing countries have a unique opportunity to take advantage of the changing system by linking to the network and then trying knowledge down locally" (ibid: 11). This linking to the network is precisely what CIDE is doing to prepare new scientists to solve regional problems, quite successfully. Finally, Arocena et al. (2015) assert that basic capacities have been developed, in some cases, to achieve high level results in the economic South.

\section{$\underline{\text { Community Development }}$}

The roots of community development, both theoretical and applied, may be found in thinkers as far back as Marx and Engels. The literature includes a number of authors who have contributed to an abundant theoretical and practical body of knowledge, particularly associated with action research, including Freire (1970), Stavenhagen (1971), de Schutter (1983), Fals Borda (1981, 1982, 1987) and others. These authors emphasize community participation as the way of enhancing development in rural (and other) areas by taking the political control of the communities and then making the "right" decisions. The orientation taken by CIDE is more in the sense of community developing not as an act of power but as the result of the conviction that development has to come from within, regardless of the power struggle. Technology plays an important part in the community development process. Indeed, "To be successful, applying technology requires the practitioner to carefully consider and select the appropriate technologies; incorporate hard technologies (solar cells, irrigation systems and other tools) and effective techniques for using them; and develop a plan encompassing all of the activities associated with using technology, from the initial investigation to maintenance and support" (Colorado State University 2015). In that respect, CIDE's professor-advisors, by the nature of its principles, stands at the frontier of technological advances, subject to the economic capacities of the social environment.

There is a common misunderstanding between development and growth. As Ackoff mentioned "To develop is to increase one's ability and desire to satisfy one's own needs and legitimate desires and those of others" (Ackoff 1977, 1986: 24); whereas growth is the increase of some tangible object. For instance if the number of cars produced in a plant increases, we rightly may say 
that the car production is growing. Whereas if the quality of working life of its workers is increasing, then it is clear the plant is developing.

\section{A Brief History of CIDE}

Miguel Arenas and a group of concerned academics started to prove his methodological ideas in the early 80's at the Faculty of Medicine and Nursery, University of Zacatecas, central Mexico. Perhaps the first time he implemented his method in full, was in 1987 at the same University, with the creation of a Masters' Program in Animal Production in Arid Zones. In two years, the students lived the experience of reading, reflecting, experimenting and writing in a way they have never done in the past (López-Pérez and Juárez-López 2012: 24-25). It could be said we transformed a part of the reality and, by doing so; we transformed ourselves, points out Raúl Villegas, a student of this program (ibid: 25).

Earlier in 1985, Arenas and associates proposed the creation of the University Centre of Research in Agriculture and Livestock at the University of Colima, campus Tecomán, central Mexico. The Centre's aim was to support the academic improvement of the staff, to promote the scientific research of production in this dry tropic region, and to find answers to the regional problems of these eco-regions. Ten years later the Tecomán group of researchers, all alumni of Arenas, consolidated and became the first regional scientific community. In 1998, a group of researchers who got their doctoral degrees in Tecomán, headed by Arenas and collaborators decided to create a new regional scientific community in the State of Coahuila, Northeast Mexico. They were well received at the Antonio Narro University, campus Torreón. This new academic adventure led to formalize the Arenas group by making official the existence of the "Centre for Innovation and Educational Development (Centro de Innovación y Desarrollo Educativo, CIDE) ", as a civil association, in June 23th, 2000 (López-Pérez and Juárez López 2012: 25).

In 2003 some CIDE members participated in the design of the higher education program of the "Justo Sierra Studies Center (Centro de Estudios Justo Sierra, CEJUS)". CEJUS is an outstanding educational project located high in the mountains of the Sinaloa state, Surutato, Northwest Mexico (CEJUS 2004). The professional studies deal with disciplines related to sustainable exploitation of natural resources in congruence with the Surutato natural wealth. Later in the same year CEJUS and CIDE agreed to let CIDE take charge of CEJUS' higher education. Since CEJUS has official recognition for granting academic degrees, it became very attractive for CIDE students dispersed around the country to register in CEJUS-CIDE to formalize their academic work and eventually, get the corresponding degree. Why did both institutions agree on working together? Because both professed the same educational philosophy, and a coincidence in the application of learning methods: emphasis on learning not teaching; education centered on the student, PBL, individual and group studying. 


\section{The Arenas Method}

The Arenas Method (AM) was developed by the initiative and knowledge of Miguel Arenas and a group of scholars interested in the creation of regional scientific communities in some of the marginal areas of Mexico (López-Pérez and Juárez-López 2012: 19-40). They had adjusted a conjunction of learning methodologies in an innovative and useful way in order to solve real problems in a specific region. Their main objectives are to contribute with the regional development and the creation of socially responsible scientists interested in improving their milieu.

The main components of the AM are as follows: a. Problem-based learning; b. construction of scientific competences and their related learning products; c. continuous socialization of knowledge; d. reflective practice; e. mentors as transformational leaders; f. learning-by-doing; g) team working, g. peer reviewing; and h. inquiry action method (López-Pérez and Juárez López 2012: 19-159).

The socialization of knowledge is being done in inter-disciplinary and multi-level groups throughout periodical discussions, peer collaboration and the use of ICT's. The method enhances that students identify the global leaders in their field of study, the state of the art, and the main recognized journals in the field. Because, "We are what we read" (López-Pérez and Juárez-López 2012: 21), students should be lifelong learners and consider the benefits from the collective intelligence created by sharing knowledge and learning from others' experience.

Horizontal collaboration between learners and mentors is a key feature in order to allow a self-directed learning in the absence of mentor's oppression (López-Pérez and Juárez-López 2012: 117, 123). It is feasible due to the enhancement of trust among members, intellectual independence, and constructive discussion related to ideas not to individuals. Education is identified as a shared learning responsibility between learners and mentors, in which the metacognition and the inner development of each individual are essential. The development of particular learnings associated with a specialized field is important as much as developing research-scientific competencies and self-development. For instance, self-esteem, self-efficacy and self-regulation are seen as relevant traits of learning related to motivation and freedom.

The AM is based on the democratization of knowledge, a humanist psychological perspective, and the pedagogy of freedom of Paulo Freire (1970). The AM asserts that we can transform our reality by transforming ourselves. Hence, the AM creates not only scientists but citizens (López-Pérez and Juárez-López 2012: 31) who will work as discoverers and significantpertinent problem-solvers. 


\section{Brief Account of the Centro De Estudios Justo Sierra, (Justo Sierra Studies Centre, CEJUS)}

The Justo Sierra Studies Centre, CEJUS, is a very important project of alternative education of high regional impact. It is located, as mentioned earlier, in the rural community of Surutato, highly isolated in the Northwest mountain range of Mexico, Sinaloa State, in an area of vast natural resources. In addition to a large forest area, the region's climate is ideal for cattle breeding and fruit and flower production; it also is highly propitious for the storage and preservation of grains as well. The Centre is created in 1978, responding to the needs of the community of a better elementary education (Comité de Planeación Educativa 1980: 19). The parents continued to demand educational services of quality and by 1982 pre-schooling and post-primary education up to high-school were established in CEJUS. In the past, beyond the elementary level, students who wished to continue learning did not have other alternative but move to the nearest urban centres: Culiacán or Guamúchil. This was a first obstacle of continuing education, since many families could not bear the expenses implied. Those that could, however, were not satisfied with the education received since the youth tended to lose their community roots, developing social and material needs alien from their own family and community. On the other hand, Surutato is within the bounds of what is called the golden triangle, a large region that spans three of the country's states, where illicit activities, namely the production and traffic of narcotics, take place intensively. Therefore, the parents are confronted with the dilemma of letting their children go or exposing them to be absorbed by the regional delinquency.

Since 2003, the Centre boasts of the creation of the Universidad de la Sierra (University of the Mountain Range), offering from the Bachelors', Masters', and Doctoral degrees in disciplines related to the sustainable exploitation of the natural resources of the region (CEJUS 2004). The fundamental reason why the community created this educational opportunity is expressed by the following text taken from the foundational document:

".... perhaps the most worrying of penuries and problems is the violence that the production and commercialization of marihuana and poppy produce in the communities and roads of the region. Unemployment, lack of communications and the call for easy money, in a frame of violent dispute for the drug market, cuts off lives and makes uneasy the daily life of individuals, families and the region" (CEJUS 2004: 15).

Participative planning is successfully practiced in Surutato (Jiménez 1992, 2008a, 2008b, Jiménez and Marín 2013) by both adults and students. The community is aware that the future can be modified by communally made decisions and actions. They are in a process of development, not in the conventional sense of continuously acquiring more goods and services, but in 
Ackoff's sense expressed at the time as the "capacity defined by what they can do with whatever they have to improve their quality of life and that of others." (Ackoff 1977: 210). The entire project is imbued with a philosophy of development similar to Ackoff's. In the words of Surutato's Educational Planning Committee:

"The fundamental objective of basic education is to help human beings to understand their immediate problems, and provide them with the proper training to solve their problems by themselves" (Comité de Planeación Educativa 1980: 2).

\section{Results}

Since the CEJUS-CIDE agreement, fifteen doctoral degrees have been granted, some of which are outstanding in their own areas of specialization: Biology, Medicine and Climate Change. Table 1 displays some data of the $\mathrm{PhD}$ graduates. The average age is 49 , considerably higher than the ordinary age of $\mathrm{PhD}$ recipients. This is due to the fact that while attending a full-time job, ordinarily in the academia, they took the advantage of joining an alternative academic track which allows them to advance in their studies without having to attend classes in the conventional mode. Most of them, 93\%, work in public institutions.

Table 1. CEJUS-CIDE PhD Graduates since its Association with CEJUS

\begin{tabular}{|c|c|c|c|c|}
\hline \multicolumn{2}{|c|}{ Examination Date } & Name & Age & Place of Work \\
\hline 1 & July / 2008 & Rocio González & 48 & Public Health Institute \\
\hline 2 & July / 2008 & Víctor M. Wilson & 40 & Public University \\
\hline 3 & July / 2008 & Ángeles Verduzco & 59 & Independent \\
\hline 4 & Nov / 2008 & Rosa Xicohténcatl & 52 & Public University \\
\hline 5 & Nov / 2008 & Carmen Reza & 38 & Public University \\
\hline 6 & Nov / 2008 & Nora Fernández & 53 & Public University \\
\hline 7 & Aug / 2009 & Marcos Bucio & 47 & Public University \\
\hline 8 & Nov/ 2009 & Ramiro Álvarez & 50 & Public University \\
\hline 9 & Jan / 2013 & Norma E. Dominguez & 48 & Public University \\
\hline 10 & Nov / 2013 & Félix S. Juárez & 55 & Public University \\
\hline 11 & Nov / 2013 & Alberta L. Granada & 58 & Public University \\
\hline 12 & Nov / 2013 & Victor M. Salomon & 48 & Public University \\
\hline 13 & Nov / 2014 & Maria N. Herrera & 43 & Public University \\
\hline 14 & Nov / 2014 & Ana F. Sandoval & 46 & Public University \\
\hline 15 & Dic / 2014 & Miguel A. Aguilera & 52 & Public University \\
\hline
\end{tabular}

Source: personal communications, Jiménez 2012: 122, and CIDE-CEJUS 2015.

Some of the outstanding dissertations presented at CEJUS-CIDE are described next, extracted from Jiménez (2012: 121-122). 
Rocío González's doctoral thesis' name is "Molecular identification of Coccidioides SPP in the Comarca Lagunera Region, in Northeast Mexico: a new endemic area for Coccidioidomicosis" (González, 2008). Coccidioidomicosis is considered the second most common fungus infection in Southwest USA. At the time she became interested in approaching the nature of this disease Dr. González was working in a third-level public hospital in the city of Torreón, Northeast Mexico, as a mycotic laboratory technician. She noticed a number of patients passed through first- and second- level medical treatment with a flawed diagnosis of pneumonia. When reaching the third-level many were not able to survive. Her research led to identify the geographic site where this infectious disease is located, in "Comarca Lagunera" Northeast Mexico. Once the endemic area has been identified, it is possible to take measures to prevent the population from getting infected by this fungus disease, reducing the mortality because of lack of prevention. Figure 2 displays the geographic regions where coccidioidomicosis is endemic.

Figure 2. Regions where the Coccidiodomicosis Takes Place, both in Mexico And South USA

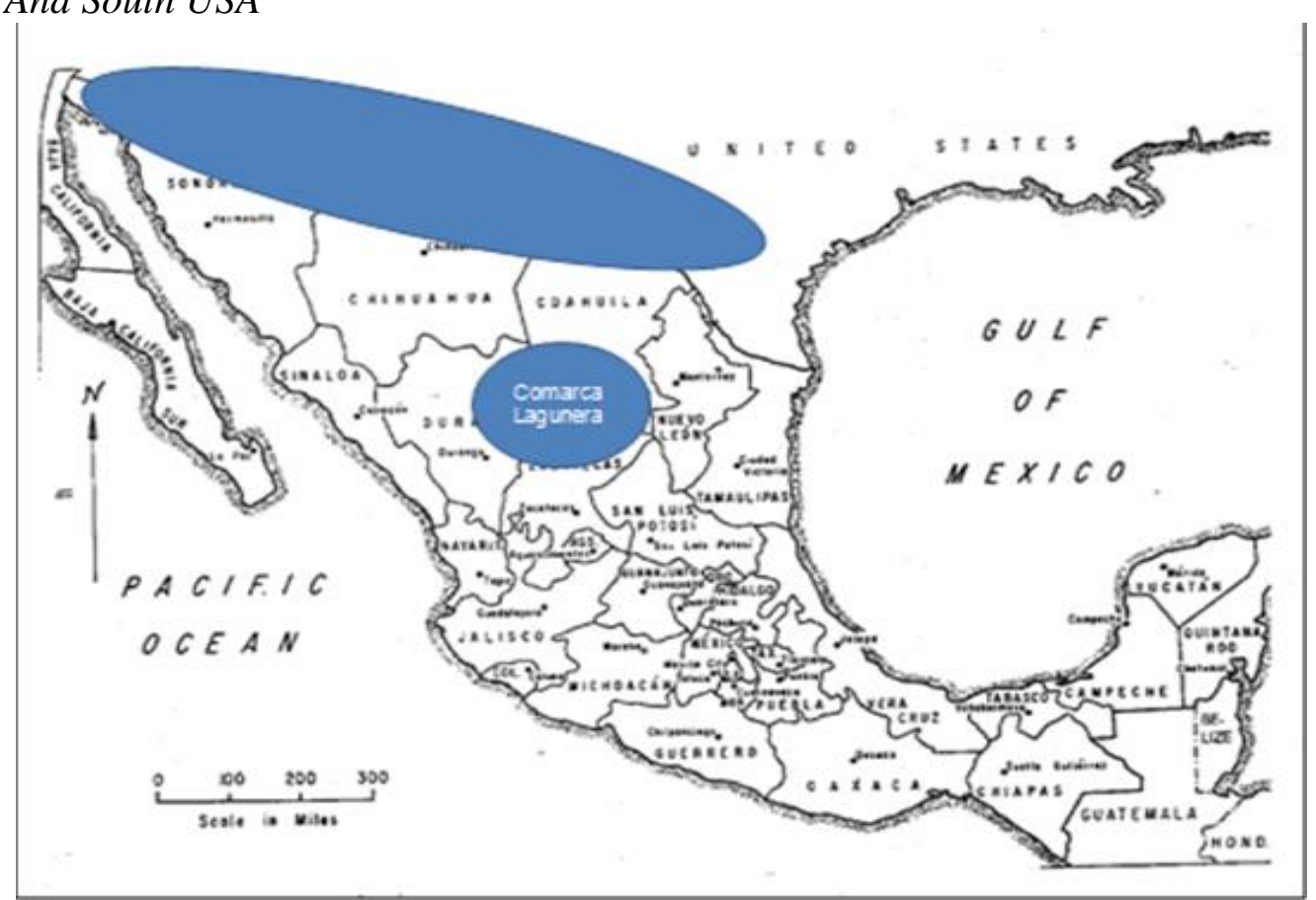

Source: Own elaboration from Rocío González dissertation (Jiménez 2012).

Víctor Manuel Wilson Corral's doctoral thesis is named "Hyperaccumulation of gold chemically induced in eight vegetable species" (Wilson, 2008). Gold phytomining has been proposed as a viable alternative for the recovery of gold from some areas of mine tailings. The level of gold that can be accumulated by plants is a function of the concentration of gold in the substrate. At the time of the realization of Víctor's research there were only two experts in the world in phytomining, one in Switzerland and the other one in New Zealand. Víctor tried to get in touch with both, being Dr. Christopher 
Anderson from New Zealand who corresponded and supported Víctor's research. The tailings dams of four mines located in the Mexican state of Sinaloa were selected for investigation of their average concentration of gold. Eight species were selected for experimentation. Based on the gold concentration accumulation, four species were selected with the potential to be used in commercial-scale gold phytomining. The experience accumulated by Dr. Wilson served him to be considered as a world expert in phytomining.

Marcos Bucio Pacheco's dissertation title is "Identification of an arid corridor South of the Sonora desert: evidence of the global warming in the photosynthetic activity" (Bucio, 2009). Bucio analyzed images taken by satellite for a number of years since 1970 to identify how an ecologically stressed corridor was increasing gradually, south of the Sonora desert. Sonora is the state North of Sinaloa. He arranged a series of satellite images to show how this corridor was growing. His point of departure was the detection of a population shift of desert rats which appeared far beyond the original desert limits. Bucio's findings are an evidence of the climate change taking place since the 1970s.

One of the most important characteristic of CIDE's model is the emphasis on the analysis and exploitation of the frontier literature in the students' corresponding area of research. This allows them to eventually get in personal communication with top scientists in the field, as mentioned before, enhancing their national/international network, opening the door to take part in foreign academic conferences and, in some cases, collaborate in the research of mainstream scholars, thus gradually inserting into international scientific networks. Table 2 displays the names of some mainstream scientists contacted by $\mathrm{PhD}$ students during and after the conclusion of their research (Jiménez 2012: 123). CIDE encourages research to solve local/regional problems felt by the communities and detected by the students. This fact fulfills CIDE's objective to contribute to the application of science to solve local/regional problems, making a reality to put science at the service of less developed communities.

Table 2. Some "Global" Communications by Phd Students Made During their Academic Work.

\begin{tabular}{|c|c|c|c|}
\hline Name & Field & Impact & Intl. Contacts \\
\hline $\begin{array}{l}\text { Rocío } \\
\text { González }\end{array}$ & $\begin{array}{l}\text { Mycotic } \\
\text { Diseases }\end{array}$ & $\begin{array}{c}\text { Regional / } \\
\text { Global }\end{array}$ & $\begin{array}{l}\text { Dr. Demostenes Pappagianis. } \\
\text { Faculty of Medicine, U. of } \\
\text { California, Davis. }\end{array}$ \\
\hline $\begin{array}{l}\text { Víctor M. } \\
\text { Wilson }\end{array}$ & Phytominery & $\begin{array}{l}\text { Regional / } \\
\text { Global }\end{array}$ & $\begin{array}{l}\text { Dr. Christopher W. N. Anderson. } \\
\text { Natural Resources Inst., U. Of } \\
\text { Massey, New Zealand. }\end{array}$ \\
\hline $\begin{array}{l}\text { Rosa } \\
\text { Xicohténcatl }\end{array}$ & $\begin{array}{l}\text { Animal } \\
\text { Genetics }\end{array}$ & $\begin{array}{c}\text { Local / } \\
\text { Regional }\end{array}$ & $\begin{array}{l}\text { Dr. Wilfred Goldmann. Roslin Inst., } \\
\text { Edinburg, Scotland. }\end{array}$ \\
\hline $\begin{array}{l}\text { Marcos } \\
\text { Bucio }\end{array}$ & $\begin{array}{c}\text { Global } \\
\text { Warming }\end{array}$ & $\begin{array}{c}\text { Regional / } \\
\text { Global }\end{array}$ & Mario Molina, Nobel Prize, MIT. \\
\hline
\end{tabular}

Source: Personal communications and Jiménez 2012: 122. 


\section{Limitations}

CIDE works in parallel with the conventional S\&T higher education system. Since CIDE does not have installations, when needed, PhD students are allowed to do their experimental work either in laboratories belonging to the formal education system or in a National laboratory. This is possible thanks to the academic network connections of the CIDE professors-advisors. If the experiments cannot be done in the institution students or professors-advisors belong to, then they may rely on the network to do the experimental work in some laboratory chaired by a colleague outside CIDE. Therefore, CIDE could not carry out its mission without the existence of the official system.

Although CIDE contributes to the formation of new scientists in high priority areas, its number of graduates does not compensate for the deficit of high skilled scientists in the country.

\section{Conclusions}

CIDE's proposal represents a fresh and innovative approach to scientific knowledge, going straight to the core: doing research that leads to the solution of regionally felt real problems. It has the virtue of promoting learning and research that forms leaders in a specific field. As well, it is accessible to all those that are willing to carry out work in an ordered, systematic and scientific manner.

It is an innovative approach also in the sense that it reflects the needs of a less privileged segment of local societies in which the students are immersed. Thus, CIDE is an example of a social-academic entrepreneurial approach that serves as an example of Mode 3 knowledge production, which we discuss elsewhere (Jiménez 2008b, 2009). It dares to do things differently from the mainstream. It is not aimed at making a profit, but rather to the formation of people who take the responsibility upon themselves for improving their surroundings and fosters the development of the Mexican society, from the bottom-up, at local level. By combining various educational tools, as outlined above, the Centre promotes better access to education for people in the provinces and already working professionals, as well as learning that involves research projects that will have a direct impact on local communities.

CEJUS-CIDE's efforts are a valuable educational contribution in Mexico. This is reflected in its official recognition by the Ministry of Public Education and Culture of the State of Sinaloa. Through the various scientific communities CIDE has created in different regions of the country, students in diverse graduate programs become proficient scientific researchers. This is corroborated through the experiences of its graduates (López-Pérez 2004), which helps to legitimate CIDE in the opinion of mainstream scholars, who have sometimes been skeptical about the alternative educational model for innovation and development. 
To focus on learning rather than teaching based on problems, collaborative networks, and socialization of knowledge are the strongest aspects of CIDE's approach. CIDE's practice shows that it is not necessary to build a rigid formal and expensive structure to prepare scientists in the areas of regional/local concern. CIDE's components work quasi-independently and produce human resources of quality and commitment towards the solution of urgent problems of the population. The "glue" that puts together the elements of CIDE's system is, without any doubt, the "motivation" of its members to reach personal as well as general CIDE's objectives.

Though it has thus far had a limited impact nationally, it is nevertheless quite important regionally and as such makes a significant contribution to modern Mexican society. Clearly, the production of just a few PhDs does not solve the lack of scientists in the country. However, it proves that:

- It can be done with a minimum of resources.

- A number of CIDE's methodological features should be incorporated in the official higher education.

The research question "how to increase the number of scientists dedicated to local/regional development in Mexico?" is positively answered with the CIDE model for the formation of scientists dedicated to the regional Mexican problematique.

\section{References}

Ackoff RL (1977) National development planning revisited, Operations Research 25(2): 207-218. Available at: http://bit.ly/10O25Hr.

Ackoff RL (1986) Management in small doses. New York: John Wiley and Sons.

Ackoff RL, Greenberg D (2008) Turning learning right side up: putting education back on track. Philadelphia: Wharton School Publishing.

Arocena R, Göransson B, Sutz J (2015) Knowledge policies and universities in developing countries: Inclusive development and the "developmental university". Technology in Society 41: 10-20. DOI= 10.1016/j.techsoc.2014.10.004.

Bucio M (2009) Identificación de un corredor árido al sur del desierto de Sonora: evidencia del calentamiento global en la actividad fotosintética [Identification of an arid corridor South of the Sonora desert: evidence of the global warming in the photosynthetic activity]. Doctoral dissertation presented at Centro de Estudios Justo Sierra, Centro de Innovación y Desarrollo Educativo. Surutato, Badiraguato, Sinaloa, México.

CEJUS (2004) Educación Superior [Higher Education]. Surutato, Badiraguato, Sinaloa, México: Centro de Estudios Justo Sierra.

CIDE (2003) Plan de Desarrollo del Centro de Innovación y Desarrollo Educativo, S. C. [Development Plan of the Centre for Innovation and Educational Development, S. C.]. Mexico [Private document].

CIDE-CEJUS (2015) Centro de Innovación y Desarrollo Educativo-Centro de Estudios Justo Sierra, Método Arenas [Centre for Innovation and Educational 
Development-Justo Sierra Studies Centre, Arenas Method]. Available at: http://bit.ly/1I91agb [Accessed: 19 March 2015].

Colorado State University on Line (2015) GSLL 1502 - Technology and CommunityBased Development. Available at: http://bit.ly/1SMqjlZ [Accessed: 13 July 2015].

Comité de Planeación Educativa (1980) Autodesarrollo Comunitario: Alternativa para el Medio Rural. Proyecto Experimental Educativo [Community SelfDevelopment: Alternative for the Rural Areas. Educative Experimental Project]. Surutato, Sinaloa, México.

de Schutter A (1983) Investigación Participativa: una Opción Metodológica para la Educación de Adultos. Centro Regional de Educación de Adultos y Alfabetización Funcional para América Latina: CREFAL [Participative Research: a Methodological Option for Adult Education. Regional Centre for Adult Education and Functional Alphabetization for Latin America: CREFAL]. México: Pátzcuaro, Mich.

Fals Borda O (1981) Aspectos Teóricos da Pesquisa Participante: Considerações sobre o Significado e o Papel da Ciência na Participação Popular [Theoretical Aspects of Participant Research: Considerations on the Meaning and Role of Science in Popular Participation]. In: Carlos Rodriguez Brandao (ed) Pesquisa Participante. Sao Paulo: Brasiliense.

Fals Borda O (1982) Participatory Research and Rural Social Change. Journal of Rural Cooperation 10(1): 25-40. Available at: http://bit.ly/1D8oZrT.

Fals Borda O (1987) The Application of Participatory Action Research in Latin America. International Sociology 2(4): 329-347. Available at: http://bit.ly/1Ky Hm96.

Freire P (1970) Pedagogy of the oppressed. New York: Seabury Press.

González M R (2008) Identificación molecular de Coccidioides spp. en La Comarca Lagunera: una nueva área endémica para Coccidioidomicosis [Molecular identification of Coccidioides spp. in the Comarca Lagunera: a new endemic area for Coccidioidomicosis]. Doctoral dissertation presented at Centro de Estudios Justo Sierra, Centro de Innovación y Desarrollo Educativo. Surutato, Badiraguato, Sinaloa, México.

Jiménez J (1992) Surutato: an experience in Rural Participative Planning. In: J-M Choukroun, R Snow (eds) Planning for Human Systems: Essays in Honor of Russell L. Ackoff: 407-416. Philadelphia, USA: University of Pennsylvania Press. ISBN: 0812231287.

Jiménez J (2008a) Surutato and the Centro de Estudios Justo Sierra (CEJUS) community development through education. In: J Jiménez Participation and Development in Mexico. How to involve people in their own development: 65-95. Germany: VDM Verlag Dr. Müller. Saarbrücken. ISBN: 978-3-639-09228-8.

Jiménez J (2008b) Research socially responsible: may we speak of a mode 3 knowledge production?. Electronic Journal of Communication, Information \& Innovation in Health 2(1): 48 - 56. Rio de Janeiro, Brazil. ISSN: 1981-6286.

Jiménez J (2009) New collaborative forms of doing research. In: A Dennis, D Kalekin-Fishman (eds.) The ISA Handbook in Contemporary Sociology. London: SAGE Studies in International Sociology: 91 - 105. ISBN: 978-1-4129-3463-3.

Jiménez J (2012) How third world countries can take advantage of globalization - a Mexican experience in learning and research. In: Z Delic (ed) Globalization and Responsibility: 113-126. ISBN: 978-953-51-0655-5.

Jiménez J, Marín R (2013) A systems approach to education in a rural poorly developed environment. In: International Association of Technology, Education 
and Development (IATED), Proceedings of the ICERI2013 6th International Conference of Education, Research and Innovation. Seville: November 18th20th, 2013: 3551-3562. ISBN: 978-84-616-3847-5.

Keane Shaw J, Allison J (1999) The intersection of the learning region and local and regional economic development: analyzing the role of higher education. Regional Studies 33(9): 896-902. Available at: http://bit.ly/1KyLKEX.

López-Pérez J (2004) Discussion on the experiences of CIDE's graduates [e-mail] (Personal communication, January 8 2004).

López-Pérez J, Juárez-López S (2012) El Método Arenas. Aplicación del PBL para la Formación de Científicos en Países con Economías en Desarrollo. [The Arenas Method. PBL Application for the Formation of Scientists in Countries with Developing Economies]. Bloomington, USA: Palibrio. ISBN: 978-1-4633-32440 .

Stavenhagen R (1971) Decolonizing Applied Social Sciences. Human Organization 30(4): 333-357. Available at: http://bit.ly/1JuH0BC.

Sun Y (2015) Facilitating generation of local knowledge using a collaborative initiator: A NIMBY case in Guangzhou, China. Habitat International 46: 130137. Available at: http://bit.ly/1fGum6A.

Wagner CS (2008) The new invisible college: science for development. Washington, D. C.: Brooking Institution Press.

Wilson V M (2008) Hiperacumulación de oro inducida químicamente en ocho especies vegetales (Brassica juncea, B. campestris, Helianthus annus Amaranthus spp., Sesamum indicum, Sorghum halepense, Amoreuxia palmatifida y Gossypium hirsutum) [Gold hiperaccumulation chemically induced in eight vegetal species (Brassica juncea, B. campestris, Helianthus annus Amaranthus spp., Sesamum indicum, Sorghum halepense, Amoreuxia palmatifida y Gossypium hirsutum)]. Doctoral dissertation presented at Centro de Estudios Justo Sierra, Centro de Innovación y Desarrollo Educativo. Surutato, Badiraguato, Sinaloa, México.

Wu F, Zhang D, Zhag J (2008) Unequal education, poverty and low growth: A theoretical framework for rural education of China. Economics of Education Review 27: 308-318. Available at: http://bit.ly/1DaBeUo. 
